\title{
経年劣化した栈橋の耐荷性を考慮した ライフサイクルシナリオに関する検討
}

\section{EVALUATION OF LIFE-CYCLE SCENARIO OF DETERIORATED OPEN-TYPE WHARF CONSIDERING DECREMENT IN LOAD CARRING CAPACITY}

\author{
山内浩 1 横田弘 $2 \cdot$ 加藤絵万 ${ }^{3} \cdot$ 岩波光保 $^{3}$ \\ Hiroshi YAMAUCHI, Hiroshi YOKOTA, Ema KATO and Mitsuyasu IWANAMI \\ 1非会員（侏日本港湾コンサルタント 九州支社（广812-0014 福岡市博多区比恵町1-1） \\ （前（独）港湾空港技術研究所LCM研究也夘一） \\ 2フェロー会員 工博 (独)港湾空港技術研究所LCM研究也外（（２39-0826 神奈川県横須賀市長瀬3-1-1) \\ 3 正会員 工博 (独) 港湾空港技術研究所LCM研究也多－（广239-0826 神奈川県横須賀市長瀬3-1-1）
}

\begin{abstract}
While lots of harbor structures have been constructed, some of them are reaching the ends of design service life. The number of structures at which remedial actions are required will be increasing rapidly. To meet the increasing number of degraded structures, strategic maintenance and repair methods should be implemented to realize life extension and structural performance recovery, resulting in minimization of life-cycle costs.

In this paper, the method is proposed to evaluate proper life-cycle scenario of deteriorated open-type wharf from the viewpoint of life-cycle cost. The change in load carrying capacity of RC members due to rebar corrosion is taken into account. Based on the calculated results, life-cycle scenarios with different repair plans were discussed from the viewpoints of recovery of load carrying capacity and the relevant life-cycle cost.
\end{abstract}

Key Words : maintenance and repair, life-cycle cost, open-type wharf, failure probability, performance level, repair cost

\section{1. はじめに}

高度経済成長期に建造された港湾構造物の多くは，老 朽化が進んでおり，必要性能を保持していない構造物が 今後加速的に増加していくことが予測される．港湾構造 物の性能を常に要求水淮以上に保持した状態で，より長 く利用するためには，効率的かつ低コストとなるマネジ メント手法の確立が必要である.このような背景の中, 近年, 港湾構造物のライフサイクルコストの検討が進め られ，多くの成果が報告されている，しかしながら，報 告された手法のほとんどは，経年劣化による性能の低下 を材料劣化による耐久性の低下に代表させて間接的，定 性的に評価しているものが多く, 終局耐力の低下を補修 対策に反映した事例は少ない。

本検討では，倸船岸の設計において支配的である地震 作用を受ける場合を考宇，劣化による終局耐力の低下を 地震被害による復旧費用（地震リスク）として定量的に 把握し, 維持管理計画に反映するため, ライフサイクル シナリオの評価を行った。 この地震被害による復旧費用,
補修費用および維持管理費用の総和をライフサイクルコ ストと定義し，ライフサイクルコストが最小となるケー スを最適なシナリオとして評価した。 また，検討構造形 式として劣化事例の報告および補修実績が多いことなど の理由により，栈橋を対象とした．栈橋の残存耐力を考 慮することで，施設に適したライフサイクルシナリオを 選択することが可能となる.

\section{2. 検討方針}

本来，栈橋は軽量であり，保有耐力が大きいため，耐 震性に優れる構造形式である. しかし, 構成材料の経年 劣化によって, 各部材の耐荷性は低下することになる. そのため, 各部材の劣化予測に基づき，部材・部位別の 補修シナリオを設定し, 設定シナリオごとの補修時の終 局耐力の低下を考慮して地震リスクを評価した.

ここで，式(1)に示すようにライフサイクルコストを 定義し，予定供用期間内に発生するコストの評価を行っ た. なお，初期建設費は考慮しなかった. 


$$
L C C=\Sigma I_{\text {repair }}+\Sigma R+\Sigma C_{T}
$$

ここに, LCC: ライフサイクルコスト, $\Sigma I_{\text {repair }}$ : 補修 費用（補修材料の更新費用を含む）の合計, $\Sigma R$ : 維持 管理費の合計, $\Sigma C_{T}$ : 復旧費用の合計（供用期間中に受 けると考えられる地震被害に対する復旧費用の期待值)

また，各部材 (部位) の劣化状態と地震リスクの関係 は以下のように考宎, 復旧費用の算定に反映した.

\section{a) 下部工}

下部工は, 設計当初に想定していた許容腐食量を超過 すると，終局耐力が低下し，地震リスクが大きくなるた め, 復旧費用が増加するものと考えた。

b) 上部工（スラブ）

上部工（スラブ）は，地震作用を考慮しないで設計さ れるため, 劣化状態と地震リスクの関連はないものと考 えた.

c）上部工（はり）

上部工（はり）は，鉄筋腐食による劣化が進行した場 合, 終局耐力が低下し，地震リスクが大きくなるため, 復旧費用が増加するものと考えた。

\section{3. 残存性能を考慮した栈橋のライフサ イクルシナリオの評価手順}

図ー1に示す評価手順の1) 3)で補修費用，4) 6)で 復旧費用を算定した. この手順に従って, 補修時の残存 性能を考慮したライフサイクルシナリオの評価を行った.

\section{（1）劣化状態の予測}

一般に, 上部工を構成する $\mathrm{RC}$ 部材の劣化進行過程は, 潜伏期 (劣化度 0 ), 進展期 (劣化度 I), 加速期 (劣化度 II $\sim \mathrm{III}$ ), 劣化期(劣化度 IV V) の 4 過程に分類される ${ }^{1)}$.

潜伏期は，鉄筋の腐食が開始する直前の状態までの期 間で，塩害においては，鉄筋位置のコンクリートに限界 量以上の塩化物イオンが蓄積されると腐食が開始される と考えられている. この塩化物イオンの限界量としては, $1.2 \sim 2.5 \mathrm{~kg} / \mathrm{m}^{3}$ の值が一般的に用いられる. これ以降の劣 化過程については，目視調查結果などから判断される定 性的指標のみで, 定量的な指標は示されていない.

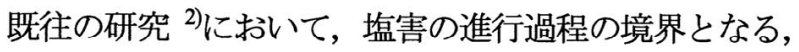

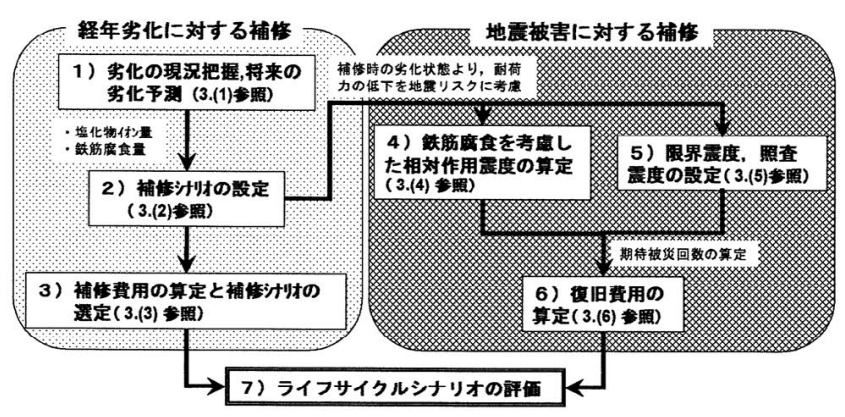

図ー1ライフサイクルシナリオ評価手順
鉄筋位置における塩化物イオン濃度が腐食発生限界に達 する時期, 腐食ひび割れの発生時期, 鉄筋腐食による体 積减少量と劣化度の関係の経時変化を定量的に評価し, 栈橋上部工の劣化予測を行う手法が提案されている.こ の手法により劣化予測を行った結果, 劣化条件を適切に 設定することで良好な予測結果を得ることができたとさ れている.ここでは，この手法を準用した.

\section{（2）補修シナリオの設定}

栈橋の補修シナリオは，下部工の腐食状態，防食工の 劣化・消耗状態, 上部工の劣化状態などから現況を把握 し, 今後の劣化予測を踏まえて設定した. 劣化予測結果 をもとに, 各部材に適用可能な補修工法と補修時期の組 合せや補修材料の更新の有無など，補修シナリオを設定 した.

各部材の補修材料については, 補修後の材料の劣化予 測を行い，更新時期の設定を行うことが重要である。し かし，環境条件および使用材料によってばらつきがある ため，現状において必ずしも全てが精度良く予測できる わけではない，したがって，本検討においては，補修材 料の更新の有無および補修工法の耐用期間に関しては, 既往の関連資料,3)参考に設定した。

\section{（3）補修費用の算定と最適補修シナリオの選定}

（2）において設定した各部材の補修シナリオについて, 供用期間中に必要となる補修費用および補修材料の更新 費用を計上した。維持管理費用が必要な補修工法につい ては，その費用も計上した。 これらの総費用が最小とな るシナリオを最適補修シナリオとして選定した.

\section{（4）鉄筋腐食を考慮した相対作用震度の算定}

上部工を構成するRC部材（はり）の鉄筋腐食と終局 耐力の関係について述べる. 設計外力として地震時の杭 頭曲げモーメントを考慮し，はりの鉄筋腐食と終局耐力 の低下の関係について評価した.

各杭の杭頭曲げモーメントは，チャンの式により算定 した. ここで, 健全なはり（終局耐力： $M_{u}$ ) が破壊す る作用震度を $k_{h 1}$, 鉄筇腐食後のはり（終局耐力： $\left.M_{u(\text { corr })}\right)$ が破壊する作用震度を $k_{h 2}$ とすると, 終局耐力の 比率は式(2)のように表すことができる.

$$
M_{u} / M_{u(\text { orr })}=k_{h 1} / k_{h 2}
$$

$M_{u}>M_{u(\text { (orr) })}$ より, 鉄筋腐食が生じたはりは, 健全時 には破壊に至らない作用震度でも部材が破壊に至る可能 性があるといえる.したがって，鉄筋腐食が生じたはり には, 便宜上, 健全時より大きな震度が作用するものと 考えることにより，この耐荷性の低下を表現する．この 作用震度を「鉄筋腐食を考慮した相対作用震度」と定義

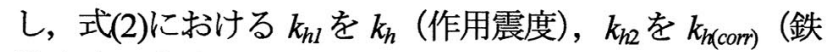
筇腐食を考慮した相対作用震度）に置き換えると，式 (3)のように表すことができる. 


$$
k_{h(\text { corr })}=\left(M_{u(\text { con })} / M_{u}\right) \cdot k_{h}=\alpha_{M} k_{h}
$$

ここに, $\alpha_{M}$ : 終局耐力低下比率 $\left.\left(=M_{u(c o r r}\right) M_{u}\right)$

加藤らの研究 ${ }^{5)}$ とると, 鉄筋腐食が生じた RC はり 部材の耐荷性は, せん断補強筋の腐食程度によらず, 主 筋の腐食のみを考慮すれば評価可能であるとされている. したがって，はり部材の曲げ破壊耐力については，主筋 の腐食のみを考慮して評価を行うこととした。

\section{（5）限界震度および照査震度の設定}

\section{a）限界震度およひ照査震度の定義}

栈橋の而震性能照查は, 簡便法, 弾塑性解析法あるい は非線形動的解析法のいずれかで検討するのが望ましい とされているす．本検討では，簡便法の照査式である式 (4)を用いて検討を行い，この式の等号が成立する作用 震度 $k_{h}$ を限界震度 $k_{k \text { (limit) }}$ と定義した. 限界震度以上の作 用震度が発生した場合，栈橋全杭の杭頭および地中部の 仮想固定点において曲げモーメントが全塑性モーメント に達するため, 全ての杭が塑性化するものと仮定する.

$$
\begin{aligned}
& R_{a} \geq k_{k} W \\
& R_{a}=\sqrt{2 \mu_{a}-1+\theta\left(\mu_{a}-1\right)^{2}} P_{y}
\end{aligned}
$$

ここに, $R_{a}$ : 地震時保有耐力 $(\mathrm{kN}), k_{h}$ : 作用震度, $W$ : 栈橋上部工自重十上載荷重（地震時） $(\mathrm{kN}), \mu_{a}$ : 許 容塑性率, $\theta$ : 荷重と水平変位の関係における二次勾配 と一次勾配の比 $\left(0\right.$ とする,$P_{y}$ : 弾性限度に対応する 耐力 $(\mathrm{kN})$

限界震度は，杭頭部の腐食が進行すると終局耐力が低 下し，小さくなるため，地震リスクが大きくなるものと 考えた.

また，設計時に杭の保有耐力照查を行った震度を照査 震度 $\left(k_{h(v e r i f i g)}\right)$ と定義した. はりの詳細設計においては, 照査震度が作用したときの断面力を設計用値として採用 しているため, これより大きな作用震度が発生した場合 には，はりが破壊に至るものと仮定した.

b）作用震度と地震被害に対する復旧範囲

本検討における栈橋の地震被害に対する復旧範囲は, 表一 1 に示すように，作用震度 $k_{h}$, 鉄筇腐食を考虑した

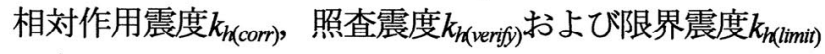
の大小によって「地震による被害なし」，「上部工の復 旧」および「栈橋全体の復旧」の3段階で判定した.

\section{（6）復旧費用の算定}

栈橋の供用期間中には，地震が複数回作用する可能性 がある.したがって，地震の規模に応じた期待被侈回数 を考慮する必要がある．構造物が設計供用期間中に被災 を受ける期待回数と期待復旧費を乗じた総和を復旧費用 と定義した.

\begin{tabular}{|c|c|c|}
\hline 作用震度 & 復旧範囲 & 備 \\
\hline $\mathrm{k}_{\mathrm{h}(\text { corr) }} \leqq \mathrm{k}_{\mathrm{h}(\text { verify })}$ & 被災なし & \\
\hline $\begin{array}{c}\mathrm{kh}(\text { verify })<\mathrm{kh}(\text { corr }) \\
\mathrm{k}_{\mathrm{h}} \leqq \mathrm{k}_{\mathrm{h}(\text { limit })}\end{array}$ & 上部工 & $\begin{array}{l}\text { 設計断面力を超過す } \\
\text { るため,はりが破壊 } \\
\text { すると仮定 }\end{array}$ \\
\hline $\mathrm{k}_{\mathrm{h}(\text { limit })}<\mathrm{k}_{\mathrm{h}}$ & $\begin{array}{l}\text { 栈橋全体 } \\
\text { (上部工，下部工） }\end{array}$ & \begin{tabular}{|l|} 
全ての杭が全塑性す \\
ると仮定
\end{tabular} \\
\hline
\end{tabular}

式(5)に期待被災回数の算定式を示す.
表-1 作用震度と被災（復旧）範囲

$$
\begin{aligned}
& \sum_{i=k}^{n} \mathrm{E}_{n i}=p_{f} \cdot v \cdot \mathrm{N}_{11} \\
& \mathrm{E}_{n k}=\sum_{i=k}^{n} \mathrm{E}_{n i}-\sum_{i=k+1}^{n} \mathrm{E}_{n i}
\end{aligned}
$$

ここに, $\sum_{i=k}^{n} \mathrm{E}_{n i}$ : 対象とする作用震度より大きな地震 が $N_{1}$ 年間に発生する期待回数 (回), $\nu$ ：対象とする 作用震度以上の地震の年発生率 $\left(=1 / T_{R}\right), T_{R}$ : 対 象とする作用震度以上の地震の再現期間 (年), $N_{1}$ : 予定供用期間（年), $E_{n k}$ : 対象とする作用震度の地震 が $N_{1}$ 年間に発生する期待回数（回）

\section{a) 期待被災回数の算定}

長尾ら》は防波堤の最適断面の選定手法として, 破壊 確率を考慮したライフサイクルコストにより評価する研 究を行っており，被災額算出において，期待被災回数を 考慮している. 本検討において，照查震度以上の鉄筋腐 食を考慮した相対作用震度が発生した場合には「被災す る」と定義しているため, 式(5)における破壊確率 $\left(p_{f}\right)$ は 1 または 0 のみを考慮し, 期待被災回数を算定した. b）地盤最大加速度の算定方法

米山ら ${ }^{8)}$ は, 過去に野田ら”放過去の地震による重力 式係船岸の被㷋事例を分析して提案した地盤最大加速度 と作用水平震度の上限值の関係式を 0.59 倍し, 地盤最大 加速度と作用水平震度の平均的な関係式を提案している. この式は, 港湾構造物に対する地域別震度を設定した際 に用いられている.

また，その際の地域別震度と基盤加速度の関係は，地 盤が第一種地盤の場合を想定しているため，式(6)に示 すように設計地点における地盤種別係数の比率を考慮す ることで，地盤条件に関係なく適用できる.

$$
\begin{aligned}
& \alpha^{\prime}=\left(\frac{k_{h}}{0.197 \times a}\right)^{3} \times g \quad(\alpha \geq 200 \mathrm{Gal}) \\
& \alpha^{\prime}=\left(\frac{k_{h}}{0.59 \times a}\right) \times g \quad(\alpha<200 \mathrm{Gal})
\end{aligned}
$$

ここに， $\alpha^{\prime}$ : 第一種地盤相当の地盤最大加速度 (Gal) , $a$ : 地盤種別係数比（=設計地点での地盤種別 係数 /第一種地盤の地盤種別係数)

\section{c）再現期間と基盤加速度の期待值}

北澤らは, 再現期間と地震動の最大加速度期待値は両 対数軸上で線形の関係であるとして，式(7)を与えてい $ろ^{10)}$.

$$
\log _{10} T_{R}=A+B \log _{10} \alpha
$$

ここに, $T_{R}$ : 再現期間（年）， $\alpha$ : 再現期閒 $T_{R}$ に対応 する基盤加速度（Gal）, $A, B$ : 回帰俰数 
ここで， $\alpha=\alpha$ '考え，文献6)に示された再現期間 75 年における基盤加速度の期待値を式(7)に代入すると, 各地域区分における再現期間 $T_{R}$ は，表－2に示す式によ り算定することができる.

\section{（7）ライフサイクルシナリオの評価}

(1) （6)に示した手順に従い，栈橋のライフサイクル コストを算定することで，最適なシナリオを選定するこ とができる.

\section{4. 既設栈橋のライフサイクルコストの算定}

\section{（1）ライフサイクルコスト算定の方針}

3. に示した評価手順に従って，図一2 に示す栈橋 ${ }^{11}$ について，ライフサイクルコストの算定例を示す. ライ フサイクルコストの算定条件は，表－3 に示寸異なる 5 ケースを設定した．表中のケース 1 を基本ケースとし， 基本ケースと異なっている条件を網猢けで表している.

また，本検討におけるライフサイクルコスト算定の前 提条件は以下のとおりである.

・ライフサイクルコスト算定の対象は栈橋本体のみとす る.

・復旧費用の算定には, 液状化を考慮しない。

・補修工事または復旧工事による供用停止期間の係留施 設使用料の損失，背後地一の経済的損失等の間接的な 費用は考慮しない。

・下部工の補修は，被覆防食の範囲では防食材の耐用年 数で防食材の更新，海中部は建設当初に想定した設計 耐用年数経過時に補強（許容腐食量超過と仮定する） する.

・復旧費用は，撤去，廃棄にかかる費用を見込んで，復 旧範囲の初期建設費の 5 割增しの費用とする.

・はりの終局耐力が健全時の $80 \%$ となった時点を使用 性能上の限界状態，60\%となった時点を安全性能上の 限界状態と仮定する．はりの安全性能上の限界状態を 下回ると通常時の要求性能を満足しないものと考え, この時点までに補修を行うものとする.

・補修費用, 復旧費用およびライフサイクルコストの算 定結果は, 栈橋本体工の初期建設費を 1.0 として, 比 率で表す。

\section{（2）上部工の劣化度の推移とはりの終局耐力の予測}

表一3 に示したケース 1 を例とし，ライフサイクルコ ストの算定結果を示す．検討手順は図一1 に示したとお りである. 他のケースも同様の手順により検討を行うた め途中過程は省略し，検討結果のみを記す。

栈橋上部工の劣化度の推移予測は文献 2)に示された 手法を準用し，はりの終局耐力は，鉄筋腐食を考慮して 予測した. スラブおよびはりの劣化度の推移予測結果お よびはりの終局耐力低下予測結果を図一 3 に示す. 本検 討ケースは, 供用後 15 年が経過しており, 劣化状態を 予測した結果，上部工の各部位の劣化度は，スラブが劣
表-2 地域区分と再現期間の関係式

\begin{tabular}{|c|c|}
\hline 地域区分 & 再現期間 $^{T_{R}}$ \\
\hline $\mathrm{A}$ & $T_{R}=10^{-2.959} \times \alpha^{\prime 19}$ \\
\hline $\mathrm{B}$ & $T_{R}=10^{-2.681} \times \alpha^{\prime 19}$ \\
\hline $\mathrm{C}$ & $T_{R}=10^{-2.497} \times \alpha^{1.9}$ \\
\hline $\mathrm{D}$ & $T_{R}=10^{-2.260} \times \alpha^{1.9}$ \\
\hline $\mathrm{E}$ & $T_{R}=10^{-1.925} \times \alpha^{1.9}$ \\
\hline
\end{tabular}

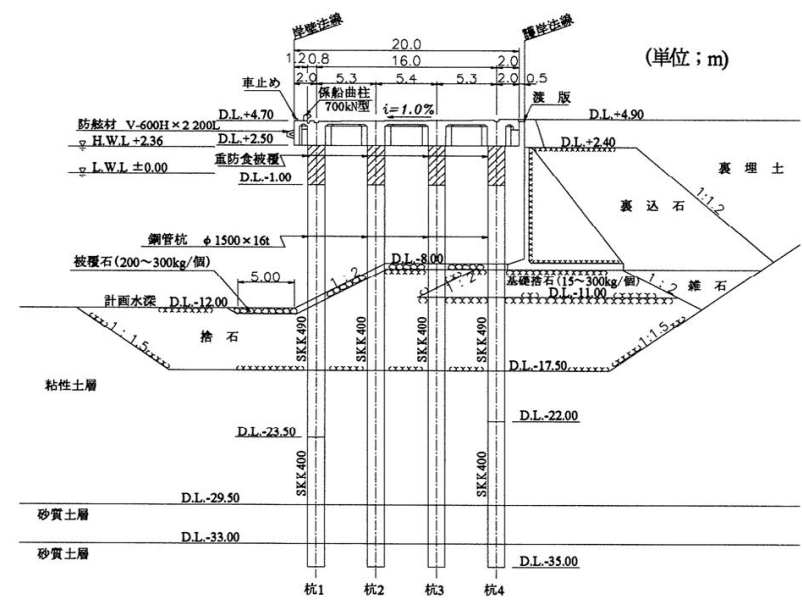

図一2 検討断面

\begin{tabular}{|c|c|c|c|c|c|}
\hline r & 检 & 条 & 件 & & \\
\hline$\pi$ & 劣化条件 & 俭即时期 & $\begin{array}{l}\text { 将来予定 } \\
\text { 供用期間 }\end{array}$ & $\begin{array}{l}\text { 照查 } \\
\text { 震度 }\end{array}$ & $\begin{array}{l}\text { 限界 } \\
\text { 罢度 }\end{array}$ \\
\hline 1 & 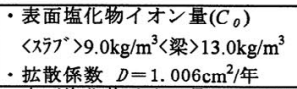 & $\begin{array}{l}\text { 建造後 } \\
15 \text { 年目 }\end{array}$ & 50年 & 0.40 & 0.43 \\
\hline 2 & 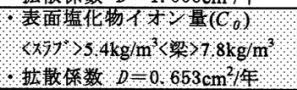 & $\begin{array}{l}\text { 建造後 } \\
15 \text { 年目 }\end{array}$ & 50年 & 0.40 & 0.43 \\
\hline 3 & 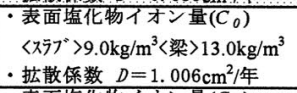 & $\begin{array}{l}\text { 建造徏 } \\
25 \text { 年: }\end{array}$ & 50年 & 0.40 & 0.43 \\
\hline 4 & 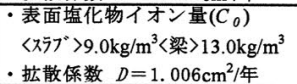 & $\begin{array}{l}\text { 建造後 } \\
15 \text { 年目 }\end{array}$ & 1004 & 0.40 & 0.43 \\
\hline 5 & 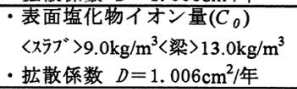 & $\begin{array}{l}\text { 建造後 } \\
\text { 15年目 }\end{array}$ & 50 年 & 030 & 0.43 \\
\hline
\end{tabular}

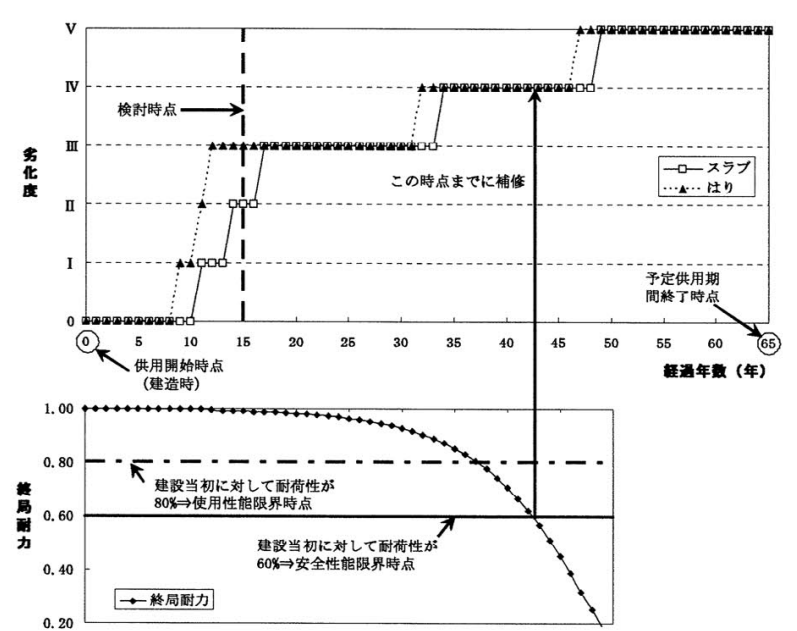

図-3 劣化度推移予測と終局耐力低下予測 
化度 II，はりが劣化度 III の状態にあると推測された。

文献2)によると，劣化度I〜III移行する時に腐食ひ び割れが入り，その後鉄筋腐食が加速的に進行すると仮 定されている. したがって, 劣化度而までは終局耐力の 低下はないと考えた。

\section{（3）補修シナリオの設定}

上部工の補修は，劣化度の推移予測結果に基づき，検 討時点および劣化度が移行する時点で行うものとした.

下部工については，前提条件に示したとおりである. これらの条件をもとに, 各部材 (部位) の補修シナリオ を設定し，検討を行った. 検討の結果，スラブは「電気 防食工法による補修（劣化度而時点）」，下部工の杭頭 部〜干満帯付近は「モルタルライニング工法」，はりに ついては, 「電気防食工法による補修（安全性能限界 時）」が最も経済的となった。

\section{（4）終局耐力の低下を考慮した復旧費用の算定}

\section{a）照査震度, 限界震度と作用震度}

3. (5)に示した手法に基づき, 照査震度および限界震 度を算定した. 算定結果より, 発生作用震度と復旧範囲 の関係は表-4に示すとおりである.

b）各作用震度の年発生回数の期待值および鉄筋腐食を 考慮した相対作用震度の算定

はりの補修時期の違いによる終局耐力低下比率の推定 結果を図一4に示す.上部工の再劣化現象をいかに本手 法に反映させていくかについては今後の課題であるが, 本検討に打いては，既設コンクリート中に残存する塩化 物イオンによる影響や飛来塩分により鉄筋腐食が進行し ないように補修を行ったものとし，補修材料の有効期間 内において終局耐力は低下せず，一定レベルの性能を維 持するものと仮定した. この結果を考慮して，鉄筋腐食 を考慮した相対作用震度の算定を行った.

\section{c）復旧費用の算定結果}

各補修シナリオに対する期待被災回数を算定し，復旧 費用を算出した。復旧費用の割合についての算定結果を 図-5に示す。

検討の結果，復旧費用は，劣化度 IIII の時点で補修を 行った場合と比べると, 使用性能限界時点では約 2 倍, 安全性能限界時点では約 4 倍となっていることが分かる.

\section{（5）ライフサイクルコストの算定}

これまでの検討結果より, 補修時の劣化状態により, 復旧費用に大きな差が生じることが分かった. 各補修シ ナリオにおける補修費用および復旧費用の算定結果をも とに算定したライフサイクルコストを表-5 に示す. 同 表には表ー3 に示した他のケースの検討結果も示してい る. また，表中の網掛け部は，各々のケースにおいて最 も経済的となったケースである.

ケース 1 における代表的なライフサイクルコストの経 年変化を図-6 および図一7 に示す. ライフサイクルコ ストが最小となったはりの補修時期が劣化度III（電気防
表-4 作用震度と復旧範囲の関係

\begin{tabular}{|c|l|}
\hline 作用震度 & \multicolumn{1}{|c|}{ 復旧範囲 } \\
\hline$k_{h(\text { (corr })} \leqq 0.40$ & 被災なし \\
\hline $\begin{array}{c}0.40<k_{h(\text { corr })} \\
k_{h} \leqq 0.43\end{array}$ & 上部工 \\
\hline $0.43<k_{h(\text { corr })}$ & $\begin{array}{l}\text { 栈橋全体 } \\
\text { (上部工, 下部工) }\end{array}$ \\
\hline
\end{tabular}

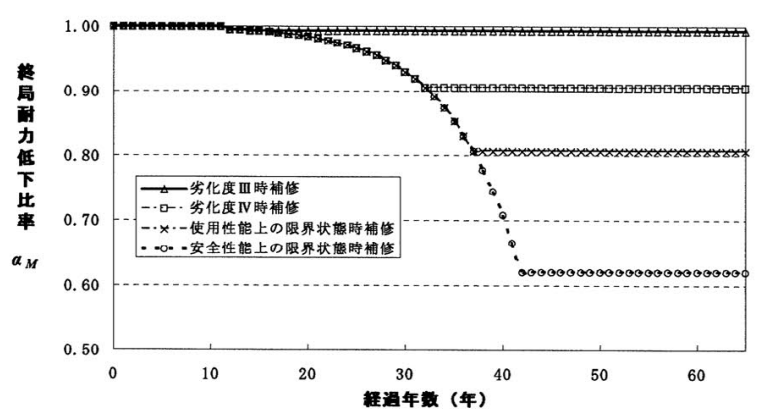

図-4 終局耐力低下比率推定図

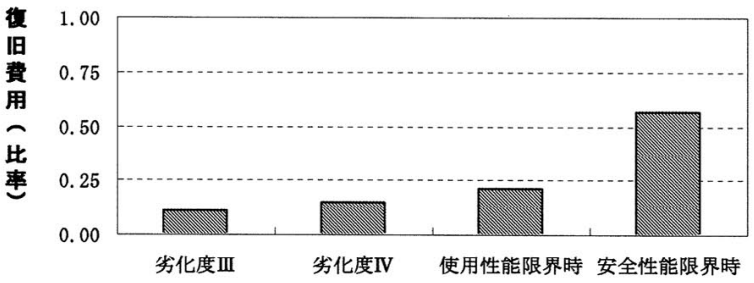

図－5 復旧費用算定結果

食）のシナリオ（図一6）に比へ，安全性能上の限界状 態で補修（電気防食）を行ったケース（図一7）におい ては，鉄筋腐食による復旧費用の増分がライフサイクル コストの約 $1 / 3$ を占めており, 補修時期を遅らせたこと により地震リスクが大きくなったことがわかる.

\section{（6）考察}

本検討では，いくつかの異なる条件でライフサイクル シナリオの検討を行った. 検討条件の違いがライフサイ クルコストの検討結果にどのように影響したか，以下に まとめる.

・上部工の劣化速度が遅いケース (ケース2) は, はり の終局耐力の低下までに時間を要するため, 地震リス クの割合は小さくなった. その結果, 補修時期の違い によるライフサイクルコストの差はほとんどなかった. ・建造後の供用期間が長く, 検討時期が遅くなるケース （ケース3）は，劣化がより進行した状態で補修を行 うこととなるため, 期待被災回数が増え, 復旧費用の 比率が大きくなった.

・予定供用期間が長いケース（ケース4）では，被覆防 食の補修工法は, 金属ライニングが最適であるとの結 果になった。これは, 補修単価は高いが，他工法より 耐久性に優れるため，ライニングの更新回数が少なく 
表－5 ライフサイクルコスト検討結果一覧

\begin{tabular}{|c|c|c|c|c|c|c|c|c|c|c|c|c|c|c|c|c|}
\hline \multirow{2}{*}{\multicolumn{2}{|c|}{\begin{tabular}{|l|} 
\\
は \\
劣化度 \\
\end{tabular}}} & \multicolumn{15}{|c|}{ ヨス 卜 比率 } \\
\hline & & \multicolumn{3}{|c|}{ 劣化度 II } & \multicolumn{3}{|c|}{ 劣化度吕 } & \multicolumn{3}{|c|}{ 劣化度IV } & \multicolumn{3}{|c|}{$\begin{array}{l}\text { 使用性能限界時 } \\
\text { (耐荷力比 } 80 \% \text { 時) }\end{array}$} & \multicolumn{3}{|c|}{$\begin{array}{l}\text { 安全性能限界時 } \\
\text { (耐荷力比 } 60 \% \text { 時) }\end{array}$} \\
\hline \multicolumn{2}{|c|}{ 補修工法 } & $\begin{array}{l}\text { 表面被 } \\
\text { 覆工法 }\end{array}$ & $\begin{array}{l}\text { 電気防 } \\
\text { 食工法 }\end{array}$ & $\begin{array}{l}\text { 脱塩 } \\
\text { 工法 }\end{array}$ & $\begin{array}{l}\text { 表面被 } \\
\text { 覆工法 }\end{array}$ & $\begin{array}{l}\text { 電気防 } \\
\text { 食工法 }\end{array}$ & $\begin{array}{l}\text { 脱塩 } \\
\text { 工法 }\end{array}$ & $\begin{array}{l}\text { 表面被 } \\
\text { 覆工法 }\end{array}$ & $\begin{array}{l}\text { 電気防 } \\
\text { 食工法 }\end{array}$ & $\begin{array}{l}\text { 脱塩 } \\
\text { 工法 }\end{array}$ & & 電気防 & $\begin{array}{l}\text { 脱塩 } \\
\text { 工法 }\end{array}$ & & & $\begin{array}{l}\text { 脱塩 } \\
\text { 工法 }\end{array}$ \\
\hline \multirow{5}{*}{ צ } & 1 & - & - & - & 1.065 & 1.020 & 1.087 & 1.073 & 1.041 & 1.101 & 1.109 & 1.104 & 1.137 & 1.464 & 1.457 & 1.492 \\
\hline & 2 & 0.987 & 0.969 & 1.010 & 0.996 & 0.959 & 1.018 & 0.987 & 0.961 & 1.016 & 0.985 & 0.986 & 1.013 & 1.086 & 1.085 & 1.114 \\
\hline & 3 & - & - & - & 1.097 & 1.052 & 1.119 & 1.100 & 1.088 & 1.128 & 1.188 & 1.157 & 1.216 & 1.684 & 1.651 & 1.712 \\
\hline & 4 & - & - & - & 2.049 & 1.984 & 2.071 & 2.103 & 2.050 & 2.131 & 2.276 & 2.205 & 2.304 & 3.307 & 3.263 & 3.335 \\
\hline & 5 & - & - & - & 1.370 & 1.326 & 1.393 & 1.464 & 1.431 & 1.492 & 1.684 & 1.679 & 1.712 & 3.014 & 3.007 & 3.042 \\
\hline
\end{tabular}

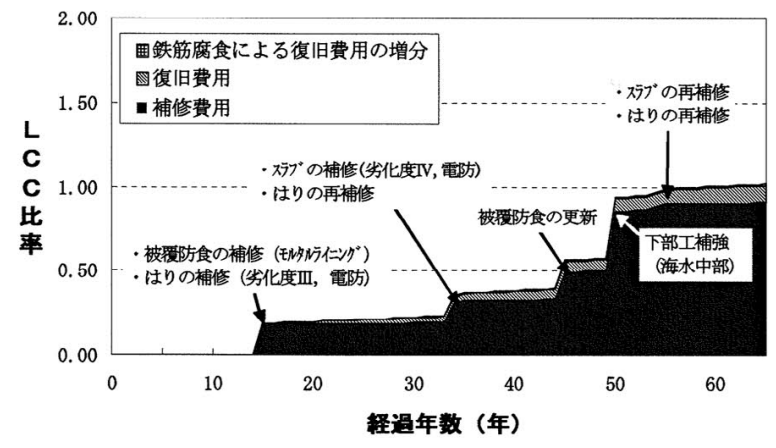

図－6 ライフサイクルコスト経時変化図 (はり補修時期 : 劣化度正)

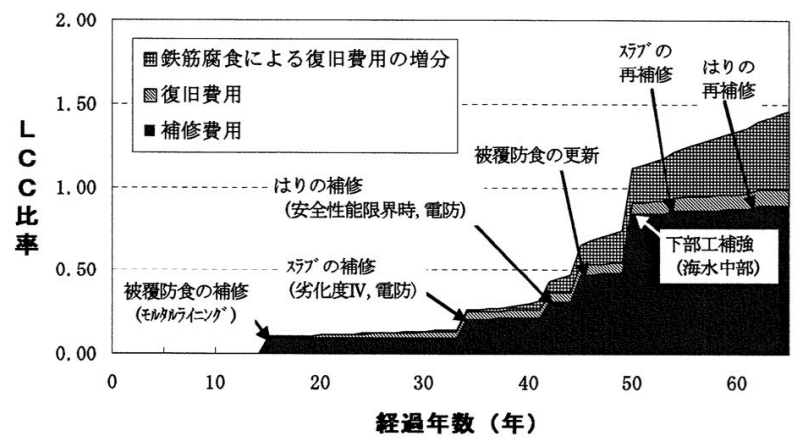

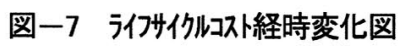
（はり補修時期 : 安全性能限界時）
なり，長期的には経済的となったためである．また， 終局耐力が小さくなって補修をすると，期待被災回数 が増えるため，補修だけでなく，更新するケースの検 討も必要であることが示唆された。

・照查震度が小さい条件（ケース 5) では, 地震リスク の影響がより大きくなるため, 期待被㷋回数が増え, ケース 1 に比へ，補修時期の差が顕著に出る結果と なった.

\section{5. おわりに}

本検討では，上部工コンクリートの劣化進行による耐 荷性の低下と地震によるリスクの増加を関連づけた既設 栈橋のライフサイクルシナリオ評価手法を示した。 また, 地震発生確率の地域区分, 地盤種別条件の評価式を用い, 地域特性を考慮した復旧費用の算定手法を提案すること ができた，同手法は，既設栈橋のみでなく，新設栈橋に おけるライフサイクルシナリオ評価にあたっても有効な 手法であると考える.

今後, 本検討で示した手法の評価結果を積極的に活用 していくためには，以下の観点に基づく検討を行うこと が必要と考える.

・劣化予測結果がライフサイクルコスト評価に与える影 響が大きいため，これらの予測を精度よく行うための 環境条件の設定

・補修時および復旧時における供用停止による施設使用 料の損失や社会的な経済損失などの間接費用の評価 ・社会的割引率の適切な設定方法

\section{参考文献}

1) 土木学会：コンクリート標準示方書［維持管理編］，2001.

2) 古玉悟, 田邊俊郎, 横田弘, 濱田秀則, 岩波光保, 日比智 也：栈橋の維持補修マネジメントシステムの開発，港湾技 研資料， No. 1001，2001. 6 .

3) 東京港埠頭公社 : 土木施設維持管理マニュアル，2004.6.

4) 防食・補修工法研究会：港湾鋼構造物調查診断・防食・補 修工法 [実務ハンドブック］，2002.2.

5) 加藤絵万, 岩波光保, 横田弘, 中村晃史, 伊藤始 : 繰返し 載荷を受けるRCはりの構造性能に及ぼす鉄笳腐食の影響, 港湾空港技術研究所資料, No. 1079, 2004. 6.

6) 運輸省港湾局監修 : 港湾の施設の技術上の基淮・同解説, 日本港湾協会, 1999.4.

7) 長尾毅, 松㴊知：破壊確率を考虑した防波堤のライフサイ クルコストと許容破壊確率，港湾技術研究所報告，Vol. 38， No. 2, pp. 395-422, 1999.6 .

8) 米山治男, 白石悟 : 港湾地域における地震荷重の変動係数 および荷重倸数の評価，港湾技研資料，№. 982，2001. 3.

9) 野田節男, 上部達男, 千葉忠樹 : 重力式岸壁の震度と地盤 加速度, 港湾技術研究所報告, Vol. 14, No. 4, pp. 67-112, 1975. 12.

10）北澤壮介, 上部達男, 檜垣典弘 : 沿岸域における基盤の最 大加速度期待値の推定，港湾技研資料，No. 486，1984.6.

11）沿岸開発技術研究センター：港湾構造物設計事例集（上 巻)，第4章直杭式横栈橋，1999. 4 